\title{
Has Macroeconomic Policy Failed Australia?
}

\author{
Garry M. White
}

\begin{abstract}
Y hould the Australian government's macroeconomic policies embody the less interventionist approach that has successfully characterised its microeconomic policies?

Economic outcomes throughout the late 1980 s and early 1990s were generally disappointing. High unemployment and an extended period of low growth were not the outcomes targeted by macroeconomic policy. True, the rapid fall in inflation to negligible levels was welcome; but it too was beyond the intentions of the government. The Australian government's highly active approach to monetary and fiscal policy during that period seems therefore to have had only a marginal effect in a world in which most major economies also experienced low growth, high unemployment and (toward the end of the period) lower inflation. Indeed, to the extent that macroeconomic policy has had any effect at all, this has probably served to exaggerate rather than ameliorate the latest turn of the business cycle.
\end{abstract}

\section{Policy Objectives}

Commonwealth Budget Papers for the period from 1988 indicate that macroeconomic policy was directed at a number of targets, particularly external balance, inflation, employment, growth and saving. The emphasis shifted after 1989 from external balance to growth and employment. As well, the framework within which the external balance issue was addressed shifted during this period from a concern about excess domestic demand to concern about the level of domestic saving. Economists should know that these are essentially different ways of saying the same thing within a general equilibrium framework. But the rhetoric surrounding policy decisions at this time suggests that many policy advisers and commentators thought within relatively partial frameworks.

The following quotations illustrate the government's shifting policy priorities throughout the period. 


\section{Table 1}

\section{Shifting policy priorities: \\ Quotations from Budget Statement No. 2 (1988/89 to 1994/95)}

\begin{tabular}{|c|c|}
\hline $1988 / 89$ & $\begin{array}{l}\text { Economic policies in } 1987 / 88 \text { continued to focus on Australia's current } \\
\text { account deficit and extemal debt position. Sustained growth in output } \\
\text { and employment and lower inflation remained important objectives. (p.9) }\end{array}$ \\
\hline $1989 / 90$ & $\begin{array}{l}\text { The adverse consequences of the exceptional demand growth for infla- } \\
\text { tionary pressures and the external accounts prompted further policy ad- } \\
\text { justments which were implemented progressively as the strength of de- } \\
\text { mand became clearer. Monetary policy had a particularly important role } \\
\text { to play. (p.2.8) }\end{array}$ \\
\hline $1990 / 91$ & $\begin{array}{l}\text { Monetary policy settings continued to be directed duning } 1989 / 90 \text { towards } \\
\text { overcoming excessive demand pressures, and the associated worsening } \\
\text { of inflation and the current account deficit, that had developed in 1988/89. } \\
\text { Those settings also had regard to the underlying need to reduce, in an } \\
\text { enduring way, Australia's high rate of inflation. (p.2.7) }\end{array}$ \\
\hline $1991 / 92$ & $\begin{array}{l}\text { The Australian economy moved into recession in mid-1990 and the la- } \\
\text { bour market deteriorated sharply from late } 1990 \text { onwards. The downturn } \\
\text { has been longer and more severe than forecast at the time of the } \\
\text { 1990/91 Budget. (p.2.2) } \\
\text { Activity and price developments in 1990/91 were influenced importantly } \\
\text { by the monetary action taken in response to the overly strong expansion } \\
\text { in } 1988 \text { and into 1989. (p.2.15) }\end{array}$ \\
\hline $1992 / 93$ & $\begin{array}{l}\text { The recovery was weaker than expected at budget time. This reflected } \\
\text { the drought, a more subdued international economic environment and } \\
\text { continued fragile business confidence. (p. 2.3) } \\
\text { Policy responded during the year to the weakness of the recovery. Addi- } \\
\text { tional expenditures of over } \$ 300 \text { million were announced in November } \\
1991 \text {. The February } 1992 \text { One Nation Statement announced a much } \\
\text { larger package of measures to boost the recovery process together with } \\
\text { structural reforms in a number of key areas. Official short-term interest } \\
\text { rates were also lowered significantly during the year, consistent with the } \\
\text { marked improvement in the inflation outlook. (p.2.4) }\end{array}$ \\
\hline $1993 / 94$ & $\begin{array}{l}\text { Reducing unemployment is the main policy challenge facing Australia. } \\
\text { (p.2.30) }\end{array}$ \\
\hline $1994 / 95$ & $\begin{array}{l}\text { The extent of any increase in the current account deficit and in extemal } \\
\text { debt as the recovery progresses will depend on the strength of the pick- } \\
\text { up in investment relative to the success in lifting national saving. (p.2.33) }\end{array}$ \\
\hline
\end{tabular}




\section{Forecasts vs Outcomes}

Official forecasts can be interpreted not only as forecasts in the traditional sense, but also as statements of how the government thinks its policy settings affect economic outcomes. They include consideration not only of the impact of external influences but also of the anticipated impact of policy.

Table 2

Budget forecasts and subsequent outcomes, 1988-93

\begin{tabular}{|l|c|c|c|c|c|}
\hline & $1988 / 89$ & $1989 / 90$ & $1990 / 91$ & $1991 / 92$ & $1992 / 93$ \\
\hline $\begin{array}{l}\text { GDP growth (\%) } \\
\text { Forecast } \\
\text { Outcome }\end{array}$ & 3.5 & 2.75 & 2.0 & 1.5 & 3.0 \\
\hline CPJ increase (\%) & 4.8 & 3.3 & -0.6 & 0.7 & 3.0 \\
$\begin{array}{l}\text { Forecast } \\
\text { Outcome }\end{array}$ & 5.5 & 7.5 & 6.25 & 3.0 & 2.0 \\
\hline $\begin{array}{l}\text { Unemployment } \\
\text { rate (\%) }\end{array}$ & 7.4 & 8.0 & 5.3 & 1.9 & 1.0 \\
$\begin{array}{l}\text { Forecast } \\
\text { Outcome }\end{array}$ & 7.25 & 6.25 & 7.25 & 10.5 & 10.5 \\
\hline $\begin{array}{l}\text { Current account } \\
\text { deficit (\% GDP) }\end{array}$ & 6.6 & 6.2 & 8.4 & 10.4 & 11.0 \\
$\begin{array}{l}\text { Forecast } \\
\text { Outcome }\end{array}$ & 3.0 & 5.0 & 4.5 & 3.5 & 3.75 \\
\hline
\end{tabular}

Source: Australian Bureau of Statistics, Cat. Nos. 5204.0, 6401.0, 6202.0, 5301.0.

Changes in GDP growth and unemployment were poorly forecast. The economy was stronger than expected in 1988/89 and 1989/90 and then weaker than expected in the subsequent two years. These forecasting errors seem explicable by reference to the pervasive impact of external developments (as discussed below) and the long lag between monetary policy decisions and their effects.

Inflation fell much faster than expected. The only overestimate (in 1989/90) was largely due to the impact of higher mortgage interest rates on the Consumer Price Index (CPI). Net of the impact of interest rates, the inflation rate in 1989/90 was 6.6 per cent.

The current account deficit was much bigger than the government expected in $1988 / 89$, when the higher interest rates of that year attracted strong capital inflows (Bewley \& White, 1990). Monetary policy takes a long time to affect activity, but it is very quick to affect international capital movements. 


\section{The Australian Experience in International Context}

Australia was far from unique in experiencing recession during the late 1980s and facing difficulties in restoring growth. In fact, the speed of Australia's recovery has been midway between that of the United States (the first out of recession) and that of Germany (the slowest to recover). This sequence of recoveries stems largely from differential policy settings. The US eased monetary policy first, but Germany continued its tight monetary policy as the Bundesbank grappled with the expansion of monetary conditions resulting from unification with the former East Germany.

\section{Figure 1}

\section{Australian and OECD industrial production, 1971-93: $\%$ change on a year earlier}

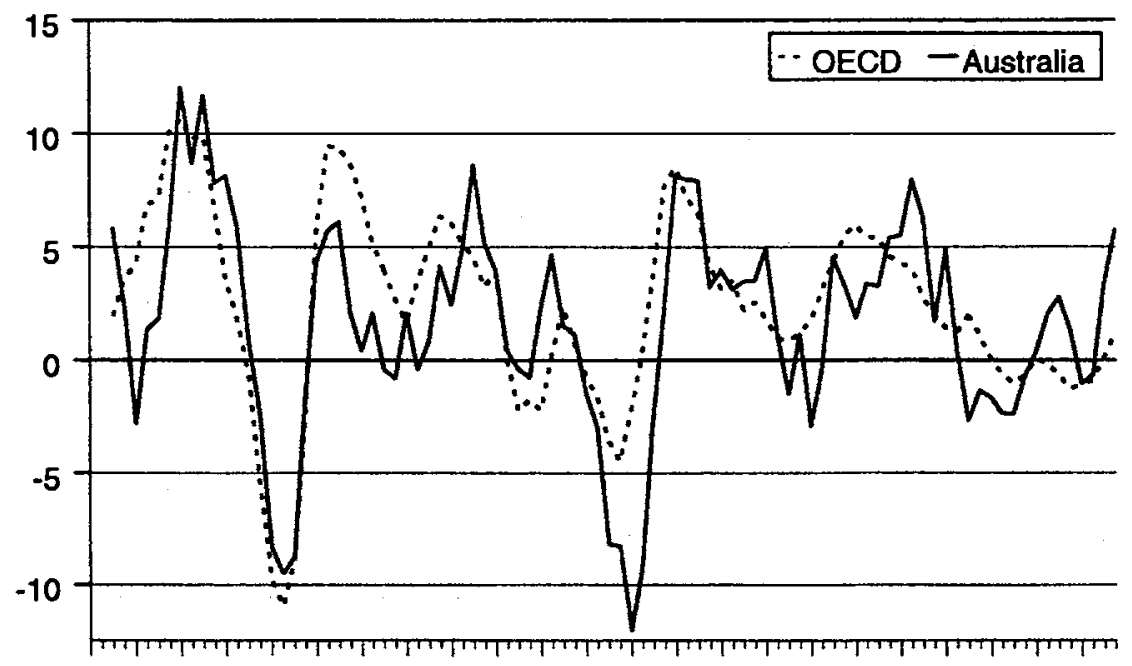

Source: Westpac/Melbourne Institute Index, reproduced in Econdata, $\dot{R B A}$ Bulletin Database, Tables G.1 and I.1

Economic growth in Australia has always been strongly influenced by international economic conditions. This close relationship is illustrated in Figure 1, which shows the growth rates of industrial production in the OECD and in Australia. Since data became available to make such a comparison in the early 1970s, industrial activity in Australia has moved closely with, or followed, activity in the major world economies. Clearly, Australia is not the engine for growth in the rest of the world. The Treasury has reported an analysis using its macroeconomic model that suggests that weaker world growth and the associated commodity price decline have 
reduced Australian GDP by around 3 per cent since mid-1990 (Budget Statement No. 2, 1993/94:2.34). Between mid-1990 and mid-1993 the economy expanded by around 4 per cent. So relatively depressed international conditions may well have reduced Australia's growth potential by around half. Unless macroeconomic policies have been perfectly coordinated, it is difficult to avoid concluding that economic activity in Australia has been largely determined by external events.

International economic activity influences domestic economic conditions mainly through commodity prices. The terms of trade (the ratio of export to import prices), which are widely used as an indicator of how well the world economy is treating Australia, tend to vary with commodity prices because import prices are relatively stable and Australia exports a high proportion of commodities. If the terms of trade are strong, then the world is willing to exchange a larger quantity of goods and services for the goods and services produced by Australia. If this is the case, Australians are wealthier. Conversely, if the terms of trade weaken, living standards fall.

Another factor that appears to have been very important in determining economic activity is the volume of output produced by the farm sector. Farm output is volatile, since it is subject to the vagaries of seasonal conditions. Even though the farm sector represented only 3.8 per cent of national output in 1992/93 (fluctuating between 3.1 per cent and 4.5 per cent since 1980/81), the volatility of output (and linkages to other sectors of the economy) is such that it can still have a major impact on economic activity. The major drought of the early 1980s, for example, provides an explanation for one of the few disparities (in magnitude though not in direction) between the growth in Australian and OECD industrial production. In 1983/84 the direct contribution of the farm sector to growth was around one percentage point. (In view of the long production response lags in respect of price changes, the impact of the change in farm output is a supply shock, distinct from the demand shock transmitted through the terms of trade.)

Figure 2 shows the relationship between the trend growth rates of GDP, Gross Farm Product (GFP) and the terms of trade. For example, the high growth of the mid-1980s was associated with a sharp recovery from drought and a strong rise in commodity prices. Similarly, the boom conditions of the late 1980 s were associated with very strong growth in commodity prices. Most recently, the recession of the early 1990 s was led by a fall in commodity prices and exacerbated and extended by a fall in farm output.

Domestic policy also had a role in the swings of economic activity. However, the difficulty the government experienced in trying to slow the economy in $1988 / 89$ and then in trying to revive it only adds to the evidence that the external economic and physical environment has a pervasive impact on economic activity. 


\section{Figure 2}

Trend output, farm product and terms of trade, 1980-94: $\%$ change on a year earlier

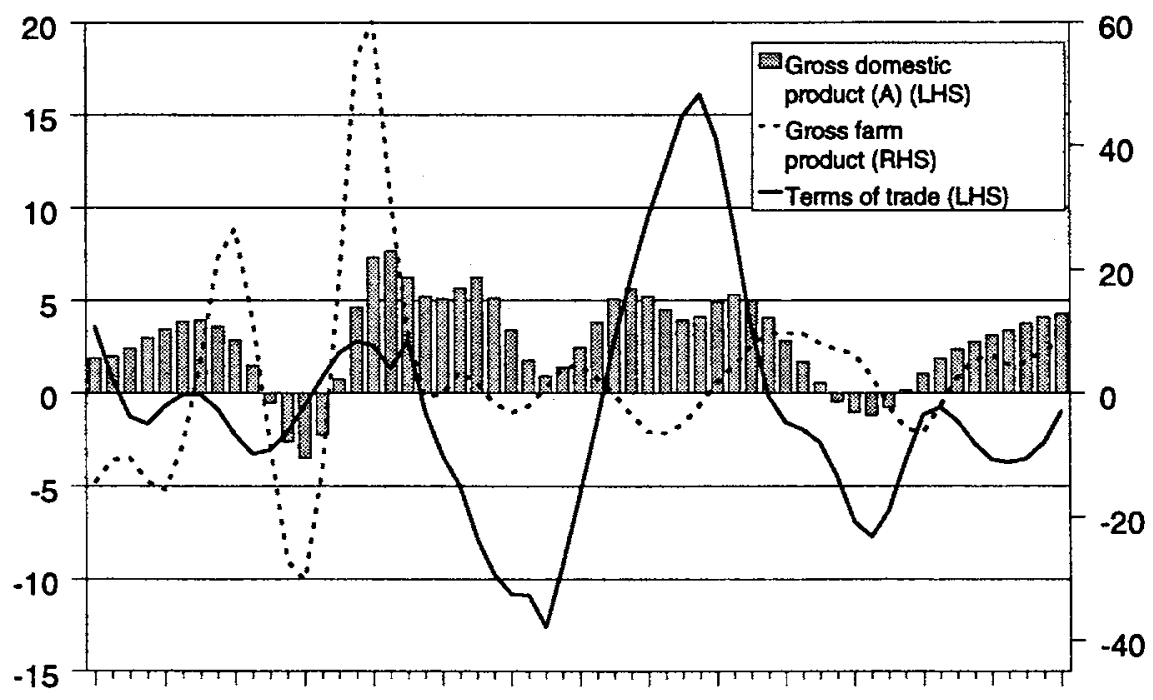

$\begin{array}{lllllllllllllll}80 & 81 & 82 & 83 & 84 & 85 & 86 & 87 & 88 & 89 & 90 & 91 & 92 & 93 & 94\end{array}$

Source: Econdata, Time Series Statistics, National Accounts

\section{The Effect of Monetary Policy}

Clearly, the level of economic activity in Australia is very strongly influenced by what happens in the rest of the world. Equally, the different experiences of the US and Germany suggest that (at least for large economies) policy settings can have a major impact on the relative performance of economies.

In a world of floating exchange rates and free international capital flows, monetary policy affects economies very largely through the exchange rate. Australia, for example, chose to float its currency and to liberalise international capital transactions in order to gain independent control over domestic monetary conditions. It is possible to control short-term interest rates or the exchange rate, but not both. Few central banks continue to target the growth of the monetary aggregates because of the instability of the velocity of money supply and the capacity of the financial sector to engineer money substitutes.

\footnotetext{
In this article, a reference to a tightening of monetary policy indicates a rise in short-term interest rates rather than a change in the money supply, thus reflecting the way monetary policy is implemented in all significant economies. Nevertheless, large increases in the money supply are inevitably inflationary.
} 
The exchange rate has a direct impact on inflation through the price of imports, import substitutes and exportables, and an indirect impact on inflation through economic activity. Changes in the nominal exchange rate usually result in a similar change in the real exchange rate with a consequent movement in the competitive position of exporters and import-competing industries. Figure 3 illustrates how, within any one year period, changes in the nominal exchange rate are only slightly offset by changes in relative inflation rates. Year-to changes in the Trade Weighted Index are compared to the same series adjusted for the CPI inflation differential between Australia and the average for OECD countries.

To put the magnitude of these changes in competitiveness into perspective, the total value of all current tariff protection is equivalent to a real exchange rate change of 6 per cent. Other forms of industry assistance are small compared to the A\$12.7 billion of gross subsidy equivalent provided to industry through tariffs (Industry Commission, 1992/93:409). Figure 3 shows that annual movements in competitiveness through changes in the real exchange rate are typically more significant than government assistance to industry.

Figure 3

Nominal vs real exchange rates, 1977-94: $\%$ change on a year earlier

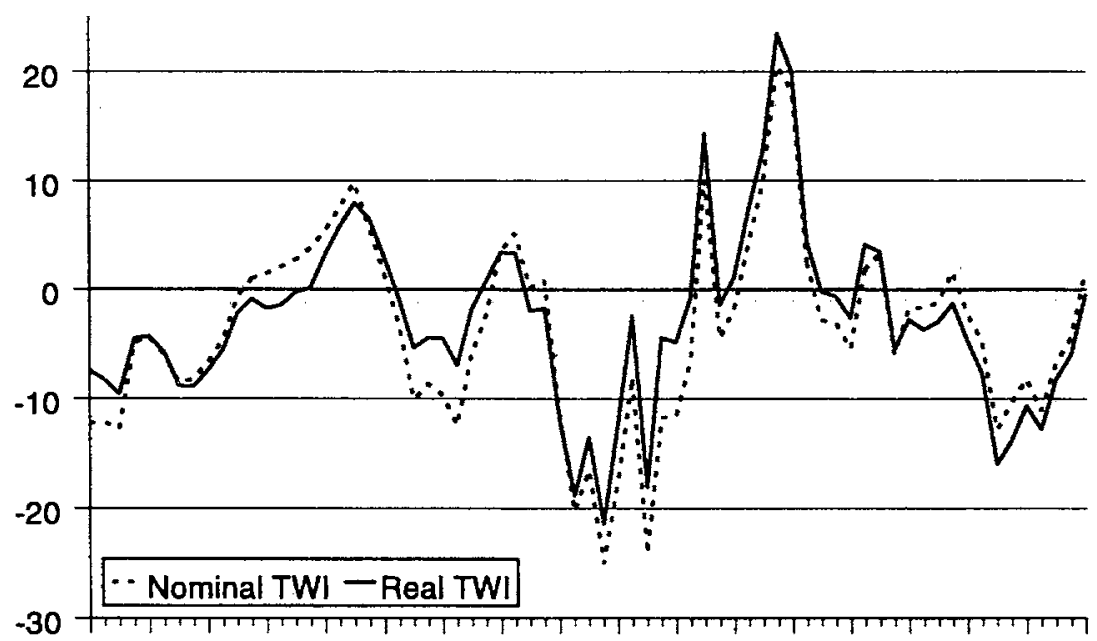

$\begin{array}{llllllllllllllllll}77 & 78 & 79 & 80 & 81 & 82 & 83 & 84 & 85 & 86 & 87 & 88 & 89 & 90 & 91 & 92 & 93 & 94\end{array}$

Source: Derived from Econdata, RBA Bulletin Database, Tables F9 and G2

However, the exchange rate is determined by a range of factors other than short-term interest rates, including commodity prices (especially for Australia), relative inflation rates, relative growth rates and myriad other factors that take the fancy 
of the foreign-exchange market. The major transmission mechanism, therefore, is far from clean. A central bank can observe the equivalent of a tightening or loosening of monetary policy while taking no action other than deciding not to alter shortterm interest rates.

Changes in the settings of monetary policy also have an impact on the balance sheets of businesses and households. However, these impacts provide offsetting effects, because households are net lenders while the business sector is a net borrower. So an increase in short-term interest rates has a first-round effect of increasing household disposable income and reducing business income. These effects can be observed from national accounts data (ABS, various years). Corporate enterprises are clearly net borrowers, and higher interest rates were a key part of the near $\$ 7$ billion increase in their net interest bills from $1987 / 88$ to $1989 / 90$ as interest rates were raised. Similarly, the gross interest bill faced by unincorporated enterprises including farmers (the interest earned by unincorporated enterprises cannot be separated from the published household sector's accounts) increased by $\$ 4.3$ billion over the same period. In contrast, the net interest position of the household sector (excluding the borrowings of unincorporated enterprises) improved by $\$ 3.6$ billion from $1987 / 88$ to $1989 / 90$, but deteriorated by $\$ 2.8$ billion as interest rates were eased.

In the short term, the1, a tightening of monetary policy tends to increase demand from the household sector (higher disposable incomes plus cheaper tradable goods) and reduce output (reduced competitiveness and lower profits from which to fund investment). In the medium term, household income is reduced as lower profits and unemployment reduce the capacity and willingness to spend.

The role of asset prices in triggering inflation in consumption and investment goods remains uncertain. How policy should respond is even more problematic. If asset prices are increasing because of higher income flows from those assets, then it would be clearly inappropriate for the government to intervene. Similarly, if higher asset values reflect genuine scarcities that require changes to relative prices in order to stimulate substitution and structural adjustment within the economy, there is no case for intervention.

In sum, higher short-term interest rates have a depressing impact on activity and inflation only after a long lag. One of the reasons for the long lag is that some of the early balance sheet impacts are perverse.

\section{Fiscal Policy and Economic Recovery}

Considerable weight has also been placed on fiscal policy as a lever to encourage a higher domestic growth rate. The Commonwealth's budget balance moved from a surplus of 2.2 per cent of GDP in 1989/90 to a deficit of 3.6 per cent of GDP in 1992/93. Subsequent years are expected to show a reduction in the deficit to 1 per cent of GDP by 1997/98. Economic conditions rendered much of this movement in the budget deficit unavoidable because of lower growth in tax receipts and increased social-security outlays. 
Since early 1991, the government's increasing concern about the recession led it to produce, in addition to its normal annual budgets, four major economic statements aimed largely at increasing the pace of economic recovery. This fiscal expansion involved both consumption and capital spending. Yet it had a smaller impact than was desired on growth, which started to revive only when there were signs that the world economy was recovering and the drought eased for much of the rural sector.

It has indeed been the conventional wisdom among many economists that greater government expenditure and higher public-sector deficits lead to greater economic activity. But this economic framework is applicable to a country with a fixed exchange rate - which Australia had when most of the economists who use it were trained. In reality, the impact of a given policy initiative is critically dependent on the prevailing exchange-rate regime. Table 3 shows how major macroeconomic policy shocks can be expected to affect a small country in a world characterised by perfect capital mobility. The table is derived from Macroeconomics in the Global Economy by Jeffrey Sachs and Felipe Larrain (1993:417-21). These authors emphasise the need to take a global approach to understanding the impact of macroeconomics. In contrast, much of the economic analysis of the 20th century reflects a perspective relevant to the US, where it was thought that the rest of the world was relatively unimportant and could be neglected for the purposes of economic analysis and policy development.

\section{Table 3}

\section{Effects of monetary policy, fiscal policy and exchange-rate policy in a small country with perfect capital mobility}

\begin{tabular}{|c|c|c|c|c|}
\hline Effect on: & \begin{tabular}{cr}
\multicolumn{2}{c}{ Monetary expansion } \\
Fixed & Flexible \\
exch. rate & exch. rate
\end{tabular} & $\begin{array}{l}\text { Fiscal ex } \\
\text { Fixed } \\
\text { exch. rate }\end{array}$ & $\begin{array}{l}\text { Fision } \\
\text { Flexible } \\
\text { exch. rate }\end{array}$ & $\begin{array}{c}\text { Devaluation } \\
\text { Fixed } \\
\text { exch. rate }\end{array}$ \\
\hline Output & 0 & & 0 & \\
\hline Price level & 0 & 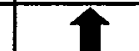 & $\overline{0}$ & \\
\hline $\begin{array}{l}\text { International } \\
\text { reserves }\end{array}$ & $\pi$ & 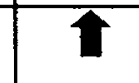 & 0 & \\
\hline $\begin{array}{l}\text { Exchange } \\
\text { rate }\end{array}$ & 0 & 0 & 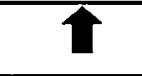 & \\
\hline
\end{tabular}

Note: The exchange-rate indicators on the bottom row show an appreciation as an ascending arrow and a depreciation as a descending arrow. This is opposite to the American exchange-rate definition used by Sachs and Larrain (1993).

\footnotetext{
${ }^{2}$ The results are based on the assumption that the economy is characterised in the short run by normal Keynesian conditions such that the aggregate supply curve is upward-sloping.
} 
The current situation in Australia is, however, very different from that of the US during earlier decades. Australia is a relatively small country with a floating exchange rate in a world characterised by volatile international capital flows. Indeed, the average daily turnover on Australian foreign exchange markets against Australian dollars has varied between $\mathbf{A} \$ 18$ billion and $\mathrm{A} \$ 27$ billion over the past year (Reserve Bank of Australia, 1994:S50). The Reserve Bank does intervene in the foreign-exchange markets at times; but these interventions are swamped by the huge size of that market. All the Bank can realistically hope to do is smooth movements in the Australian dollar against other currencies.

Sachs and Larrain would predict that a fiscal expansion (whether a cut in taxes or a rise in government spending) would boost output in a country like Australia only if it had a fixed exchange rate. Under a floating exchange rate, a fiscal expansion would fail to increase output because it would require the sale of additional government bonds, which would lead to higher domestic long-term interest rates. Higher interest rates in turn attract additional capital inflow and thereby cause the exchange rate to rise also, producing a fall in net exports. In short, the fiscal expansion is offset by a fall in net exports. But under a fixed exchange rate, fiscal expansion can stimulate activity because there is no immediate impact on international competitiveness. The sale of additional bonds can result in a rise in domestic interest rates or an increase in domestic money supply. The latter results from the central bank having to buy additional government securities and, to fund these, sell foreign-exchange reserves. The additional money supply can be expected to increase output (if there are slack resources in the economy) and to increase inflation.

An anonymous referee has raised an interesting question related to the possible equivalence of an external stimulus from stronger terms of trade (as argued above) and an expansionary fiscal policy. Why would not the currency appreciation associated with a strengthening of the terms of trade offset the direct benefits of that strengthening? The answer is that the external shock is effectively a free good, whereas a fiscal expansion must be paid for either by redirecting domestic savings from other uses or by attracting additional foreign savings (a higher current-account deficit). The currency appreciation related to a strengthening of the terms of trade is necessary to keep the current account in accord with the savings/investment balance, and it also acts to redistribute income from exporters and importers (whose margins have improved) to the rest of the economy. Most econometric studies of the relationship between the terms of trade and the exchange rate find that a given change in the former produces a less than equivalent change in the latter. That is, exporters receive a net improvement in domestic currency prices as world prices improve. At the same time, the prices of their imported and exportable inputs have fallen. An appreciation of the currency following a rise in the terms of trade also provides a net boost to the production of non-traded goods in the economy.

A monetary expansion, in contrast, has a positive impact on output under a flexible exchange rate regime but no impact if the exchange rate is fixed. Under a floating exchange rate, a monetary expansion brings lower domestic interest rates and a lower exchange rate, increasing the demand for domestically produced goods. 
Under a fixed exchange rate, an attempt at monetary expansion provokes a capital outflow that offsets the initial monetary expansion. As there is no change in the price level or the exchange rate, there can be no gain in industry competitiveness through a lower real exchange rate.

The call on private domestic or foreign savings to fund a budgetary expansion must have an adverse impact on domestic investment if long-term interest rates are increased. If long-term interest rates are higher, the private sector will be reluctant to invest in any given project, and formerly marginal projects will not proceed.

It is also possible to examine particular unanticipated shocks on the market's expectation of future fiscal outcomes and the resultant change in bond yields. During the early 1990s there was a general downward trend in bond yields as inflationary expectations fell. Around this trend, however, a number of episodes can be identified during which bond yields moved in response to a range of developments. The first was news of the need for higher bond sales in 1991/92 as the budget deficit increased beyond earlier expectations. The second was the anticipation of the fiscal expansion to be delivered in the government's One Nation economic statement of February 1992. Third was the adverse reaction to the budget for 1992/93, which confirmed the government's support for the tax cuts announced in One Nation. Each of these episodes produced a sharp rise in bond yields. A subsequent episode involved news that the government would be likely to modify or delay the promised tax cuts if it meant compromising the objective of reducing the Commonwealth's deficit to 1 per cent of GDP by the late 1990s. The bond market rallied strongly on this development.

It might be argued that the structural and cyclical components of changes in the government's fiscal position should be separated. However, this is a difficult and, inevitably, an arbitrary process. In any case, the impact of greater spending on the economy should be independent of the official purposes of that spending.

It is sounder to assume that Australia's economic cycle is fundamentally determined by external economic influences, although it can be ameliorated or exacerbated by government policies. But since the floating of the Australian dollar fiscal policy has probably had relatively little influence on the level of economic activity.

\section{Conclusion}

The effects of the different arms of macroeconomic policy cannot be separated from their interactions or from the real shocks that have a pervasive impact on the Australian economy. But what happens if, as argued above, the level of economic activity is predominantly influenced by external events (the international economy and climatic factors); policy takes a long time to have an effect; and policy-makers attempt to influence economic outcomes? There is then the real possibility (depending on the length of the world economy's cycle) that policy intervention will be stimulatory when the world economy is expanding, and deflationary when it is contracting. For example, the lag with which monetary policy affects economic activity appears to be around six quarters. The dramatic tightening of monetary policy during 1988/89, when the main factor behind the rapid growth in demand was the 
strength of the terms of trade, occurred on the assumption that the world economy would continue to expand. As it turned out, the world economy slowed and the earlier tightening only exacerbated the subsequent recession.

Following the arrival of the recession, monetary policy was eased and fiscal spending was increased. It is doubtful whether the latter produced any benefits, but higher budget deficits have clearly increased long-term interest rates. Fortunately, it appears that the recovery in the world economy will occur over a long period. In this context, the earlier easings of monetary policy in Australia are unlikely to coincide with a sharp world recovery, so rendering monetary policy appropriately supportive rather than inflationary - though more as a result of good luck than of good management.

Policy-makers may need to commit themselves to trying to do much less. If monetary and fiscal settings were subject to less change, economic growth would probably be higher on average. Although, as argued, fiscal policy has little impact under a floating exchange rate, policy changes always impose real costs. A much sounder approach would be to improve the flexibility with which the economies can respond to external shocks. Competitive and flexible product and labour markets would enable output to be maintained through externally generated downturns and minimise the inflationary consequences of externally generated periods of rapid expansion. So long as the government finances its activities through the sale of bonds to the private sector, and so long as domestic markets are competitive and open to foreign competition, it is difficult to see how inflation would become a problem during periods of high growth.

If the government were to pursue a less interventionist macroeconomic policy, two issues arise. What would constitute a neutral stance of monetary policy? And how can policy-makers be persuaded to resist the urge to seem to be 'doing something?'

\section{References}

Australian Bureau of Statistics (ABS) (various years), Australian National Accounts: National Income, Expenditure and Product, Canberra (Cat. No. 5204).

Bewley, R. \& G. White (1990), 'Do High Interest Rates Improve or Worsen the Current Account?', Economic Papers 9(4): 19-33.

Budget Statements (1988/89-1994/95), Commonwealth Govemment Budget Papers, AGPS, Canberra.

Industry Commission (1993), Annual Report 1992/93, AGPS, Canberra.

Reserve Bank of Australia (1994), Reserve Bank of Australia Bulletin, May, Sydney.

Sachs, J. \& F. Larrain (1993), Macroeconomics in the Global Economy, Harvester Wheatsheaf, Hemel Hempstead. 